\title{
Effect of Pretreatment of Rats with Carbon Tetrachloride on Tolerance Development
}

\author{
Thomas Dambrauskas and Herbert H. Cornish \\ Department of Industrial Health and Institute of Industrial Health, \\ School of Public Health, University of Michigan, Ann Arbor, Michigan 48104
}

Received July 8,1968

\begin{abstract}
The Effect of Pretreatment of Rats with Carbon Tetrachloride on Tolerance Development. Dambrauskas, Thomas, and CORNISH, Herbert H. (1970). Toxicol. Appl. Pharmacol. 17, 83-97. To evaluate the effect of pretreatment of rats with $\mathrm{CCl}_{4}$ on tolerance development to subsequent exposures, rats were exposed $25-7500 \mathrm{ppm}$ of $\mathrm{CCl}_{4}$ vapor or given $\mathrm{CCl}_{4}$ orally, $3.25 \mathrm{mg} / \mathrm{g}$ body weight. Forty-eight hours later these rats were reexposed to a normally lethal $7500 \mathrm{ppm} \mathrm{CCl}_{4}$ concentration. Mortality, blood clotting time, serum bilirubin, serum and liver triglycerides, and $\mathrm{CCl}_{4}$ and $\mathrm{CHCl}_{3}$ concentrations in tissues and in the whole rat were used as a measure of the response to $\mathrm{CCl}_{4}$ exposure. Conversion of $\mathrm{CCl}_{4}$ to $\mathrm{CHCl}_{3}$ in vitro was also determined in normal and pretreated animals. It was found that animals exposed to $4000 \mathrm{ppm}$ for $6 \mathrm{hr}$ or given $3.25 \mathrm{mg} / \mathrm{g}$ of $\mathrm{CCl}_{4}$ orally developed tolerance to subsequent normally lethal $\mathrm{CCl}_{4}$ exposures. Serum bilirubin levels in animals protected by $\mathrm{CCl}_{4}$ pretreatment were significantly lower than in those receiving only a single exposure to $\mathrm{CCl}_{4}$. Blood clotting times in protected animals were normal, while in those not protected by pretreatment, they were greatly prolonged. Serum triglyceride levels in protected animals were normal whereas they were considerably depressed in the nonprotected animals. Liver triglycerides were elevated in both protected and nonprotected, but were not as high in the protected animals. Carbon tetrachloride conversion to $\mathrm{CHCl}_{3}$ was slower in protected than in the nonprotected animals. Tolerance to $\mathrm{CCl}_{4}$ developed in animals whose ability to metabolize $\mathrm{CCl}_{4}$ had been depressed by pretreatment with the same compound. This suggests that the toxicity of $\mathrm{CCl}_{4}$ is related to its metabolic pathway or to the production of toxic intermediates.
\end{abstract}

Exposure of living organisms to certain types of stress may have injurious or tolerancedeveloping effects depending upon the type and degree of stress. Tolerance development to ozone (Stokinger, 1965; Stokinger and Scheel, 1962), protection against lethal doses of X-irradiation by preexposure to ozone (Hattori et al., 1963), reduction of radiation mortality through magnetic pretreatment (Barnothy, 1963), and protection against high doses of cadmium chloride by pretreatment with low doses (Terhaar et al., 1965) have been reported. However, the effect of pretreatment and subsequent tolerance development is not uniform, and no general concept has been developed that would enable one to predict the effect of pretreatment on tolerance development or protection.

In the present study, the effect of pretreatment of rats with carbon tetrachloride on the development of tolerance to subsequent exposures was investigated. 


\section{METHODS AND MATERIALS}

Male albino rats of the Sprague-Dawley ${ }^{1}$ strain were used throughout the studies. The animals were maintained on an ad libitum diet of laboratory chow ${ }^{2}$ except during the exposure and fasting period. Carbon tetrachloride was administered to animals by

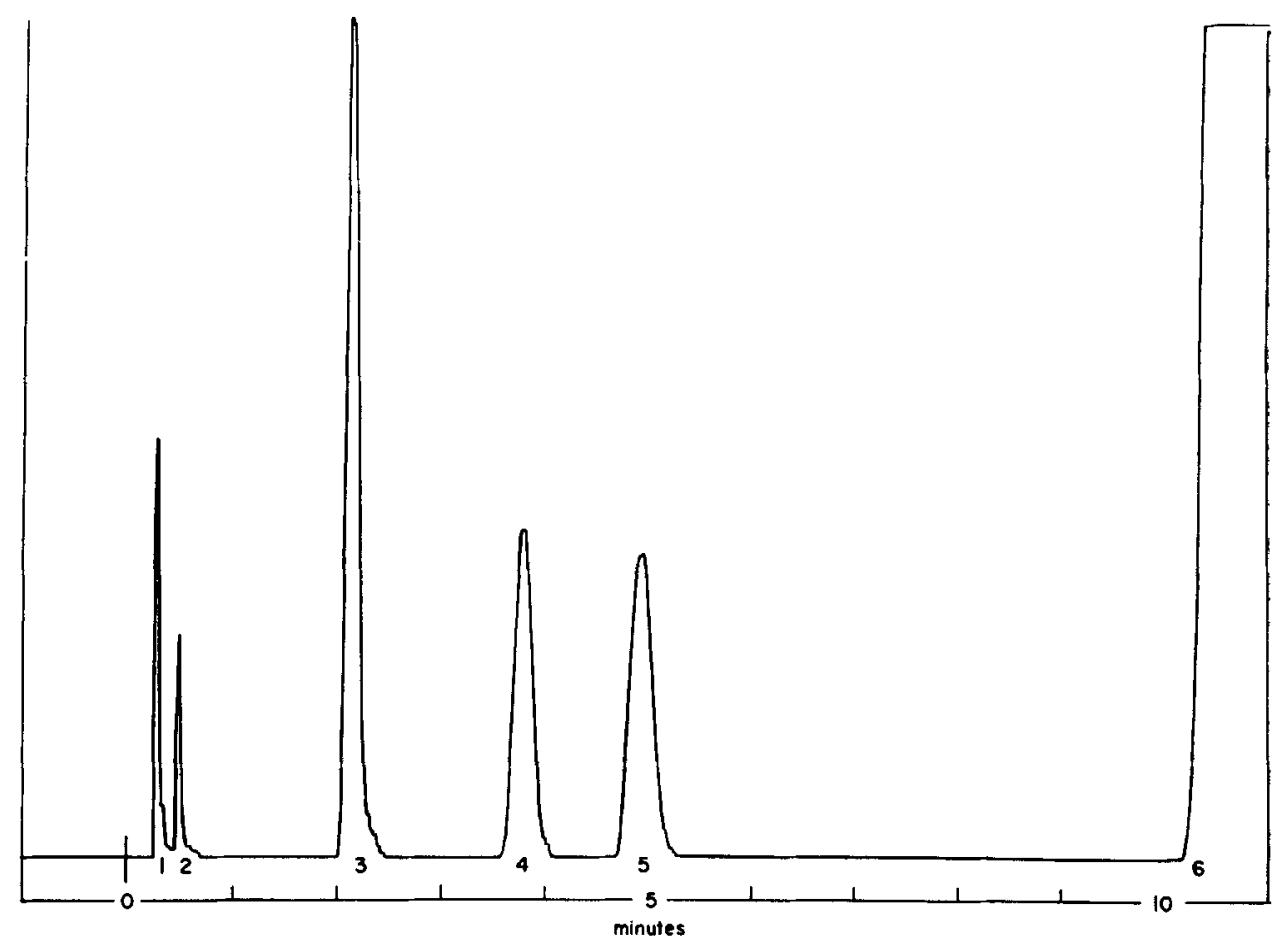

Fig. 1. Standard gas chromatogram. Peak 1 indicates $\mathrm{CH}_{4}$; peak 2, $\mathrm{CH}_{3} \mathrm{Cl}$; peak $3, \mathrm{CH}_{2} \mathrm{Cl}_{2}$; peak 4, $\mathrm{CCl}_{4}$; peak $5, \mathrm{CHCl}_{3}$; and peak 6 , toluene.

inhalation (Block and Cornish, 1958) at concentrations of $25-6000 \mathrm{ppm}, 6 \mathrm{hr}$ daily for periods of 1-5 days, and by the oral route at a dose of $3.25 \mathrm{mg} / \mathrm{g}$. Animals were reexposed to lethal levels $\left(7500 \mathrm{ppm}\right.$ of $\mathrm{CCl}_{4}$ ) at various time intervals after the first exposure. Mortality data were procured after observation of treated animals for 14 days. Groups of normal control animals were included in all studies.

At appropriate time intervals after treatment, animals were sacrificed by stunning and decapitation. Liver and lungs were removed for histopathologic examination, and liver weights were determined. Liver and lung tissues were fixed in $10 \%$ formalin, sectioned and stained with hematoxylin and eosin and Oil Red $\mathbf{O}$ for microscopic examination.

Blood clotting time was determined by the capillary tube method, and serum bilirubin by the standard Ehrlich's diazo procedure (Am. Assoc. Clin. Chem., 1953). The data were statistically processed by Duncan's New Multiple Range Test (Duncan, 1955).

Serum and liver triglycerides. Serum triglycerides were determined by the method of Van Handel and Zilversmit (1957), and liver triglycerides by the method of Butler $e t$ al.

' Spartan Research Animals, Inc., Haslett, Michigan.

${ }^{2}$ Purina. 
(1961). Normal rat serum and liver triglyceride levels were determined on four, five rat-pool samples and on five individual rat samples. Using the $t$ test for small samples, no significant difference between the mean liver triglyceride values of pooled and individual rat samples was found. Subsequent determinations of triglycerides were carried out on five rat-pool samples.

Carbon tetrachloride and chloroform analysis. Carbon tetrachloride and its metabolite, chloroform, were determined in rat tissues by microdiffusion and gas chromatographic techniques as described below.

A gas chromatograph ${ }^{3}$ with hydrogen flame ionization detector was used for gas chromatographic analysis of chloromethanes. The stainless steel $5^{\prime} \times 1 / 8^{\prime \prime}$ column was filled with $5 \%$ Ucon-water ${ }^{4}$ insoluble and $5 \%$ silicone $^{5} 550 \mathrm{w} / \mathrm{w}$ an Chromosorb $\mathrm{P},{ }^{6}$ acid washed, mesh $45 / 60$. The injector temperature at $80^{\circ} \mathrm{C}$, column temperature at $45^{\circ} \mathrm{C}$, carrier gas flow at $20 \mathrm{ml} / \mathrm{min}$, hydrogen at $20 \mathrm{ml} / \mathrm{min}$, and air flow delivered by a pump were kept constant at all times.

Mallinckrodt analytical reagent grade $\mathrm{CCl}_{4}, \mathrm{CHCl}_{3}$, and $\mathrm{CH}_{2} \mathrm{Cl}_{2}$, and Matheson $\mathrm{CH}_{3} \mathrm{Cl}$ and $\mathrm{CH}_{4}$ were used as standards for gas chromatography with toluene as a carrier solvent. The toluene, $\mathrm{CCl}_{4}, \mathrm{CHCl}_{3}$, and $\mathrm{CH}_{2} \mathrm{Cl}_{2}$ were purified by fractional distillation, and the purity was checked by gas chromatography.

The retention times of the various chloromethanes were determined by injection into the gas chromatograph of each component dissolved in toluene and by the injection of a number of mixtures of these compounds. Retention times were checked using two columns with different stationary phases. Figure 1 shows a typical chromatogram of the various chloromethanes.

The accuracy of the microdiffusion and gas chromatographic techniques was checked by the following procedure. Five-milliliter portions of diluted sulfuric acid (2:1) were introduced into 50-ml glass-stoppered Erlenmeyer flasks. A vial containing $1 \mathrm{ml}$ of toluene was placed in each flask. Known amounts of pure $\mathrm{CCl}_{4}$ and $\mathrm{CHCl}_{3}$ or their mixtures were introduced below the surface of the sulfuric acid, and the flasks were immediately stoppered. Stoppers were lightly greased with Dow Corning silicone lubricant. Samples were shaken continuously for $18-26 \mathrm{hr}$ at room temperature. Portions $(0.2 \mu \mathrm{l})$ were withdrawn from each vial of toluene and injected into the gas chromatograph; recovery of $\mathrm{CCl}_{4}$ and $\mathrm{CHCl}_{3}$ was calculated by comparison of peak areas with the standard gas chromatogram. The recoveries of $\mathrm{CCl}_{4}$ and $\mathrm{CHCl}_{3}$ ranged from 96.5 to $103.5 \%$.

The stability of $\mathrm{CCl}_{4}$ in sulfuric acid was checked by placing $\mathrm{CCl}_{4}$ in flasks prepared as above. No peaks other than that of $\mathrm{CCl}_{4}$ were found on gas chromatograms even after a 10-day period.

For the determination of $\mathrm{CCl}_{4}$ and $\mathrm{CHCl}_{3}$ in tissues and in the whole rat, rats were sacrificed immediately after exposures by stunning and decapitation. Tissues were taken rapidly and placed in separate cold 50-ml Erlenmeyer flasks. In whole rat studies, animals were opened by a ventral incision and immediately placed in 500-ml Erlenmeyer flasks. Appropriate amounts of cold, (2:1) diluted sulfuric acid were added to digest the

\footnotetext{
${ }^{3}$ Wilkins Instrument and Research, Walnut Creek, California.

${ }^{4}$ Applied Science Laboratory, Inc., State College, Pennsylvania.

${ }^{5}$ Research Specialties Co., Richmond, California.

6 Johns-Manville Corp., 22 E. 40th St., New York, N.Y.
} 
tissues. Vials containing $1 \mathrm{ml}$ of toluene were placed in each flask containing rat organs, and vials containing $2 \mathrm{ml}$ of toluene were placed in flasks containing the whole rat to absorb $\mathrm{CCl}_{4}$ and $\mathrm{CHCl}_{3}$ released from tissues. After 24 and $48 \mathrm{hr}$ shaking at room temperature, the quantity of chloromethanes in the toluene was determined as described above.

The in vitro conversion of $\mathrm{CCl}_{4}$ to $\mathrm{CHCl}_{3}$ by the liver of normal rats and by those exposed to $4000 \mathrm{ppm}$ of $\mathrm{CCl}_{4} 48 \mathrm{hr}$ prior to sacrifice was also studied ( 5 rats in each group). Normal and $\mathrm{CCl}_{4}$-treated animals were sacrificed; livers were removed, sliced (approximately $2-3 \mathrm{~mm}$ in thickness), and placed in 50-ml Erlenmeyer flasks containing $6 \mathrm{ml}$ of distilled water. One microliter of $\mathrm{CCl}_{4}$ was added to each flask; flasks were sealed immediately and incubated for 24 hours at $37^{\circ} \mathrm{C}$. At the end of the incubation period, a portion of gas was removed from each flask and subjected to gas chromatographic analysis for chloromethanes.

\section{RESULTS}

Mortality and Tolerance Development

The LD100 exposure to $\mathrm{CCl}_{4}$ was found to be $7500 \mathrm{ppm}$ for $6 \mathrm{hr}$. During reexposure studies described below, rats were exposed to $7500 \mathrm{ppm}$ for $5.5 \mathrm{hr}$ to allow survival for $24 \mathrm{hr}$ in order to provide tissues for additional studies. Even at this level of exposure, usually not more than 2 of 20 rats survived for 14 days after exposure.

TABLE 1

Effect of Pretreatment on Mortality of Rats Exposed to Carbon Tetrachloride

Exposure to $7500 \mathrm{ppm}$ of $\mathrm{CCl}_{4}$ for $5.5 \mathrm{hrs}$.

\begin{tabular}{|c|c|c|c|c|c|c|}
\hline & & & & & & \\
\hline & & & & & Su & vival \\
\hline & Pretice & MEII & & & & \\
\hline $\begin{array}{l}\text { Number } \\
\text { of runs }\end{array}$ & $\begin{array}{l}\mathrm{CCl}_{4} \\
\mathrm{ppm}\end{array}$ & $\begin{array}{l}\text { Exposure } \\
\text { (hours) }\end{array}$ & Survival & $\begin{array}{c}\text { Hours after } \\
\text { pretreatment }\end{array}$ & Pretreated & $\begin{array}{l}\text { pretreated } \\
\text { (controls) }\end{array}$ \\
\hline 1 & 6000 & 6 & $11 / 20^{a}$ & 120 & $11 / 11^{a}$ & $2 / 20^{a}$ \\
\hline 1 & 4000 & 6 & $20 / 20$ & 96 & $20 / 20$ & $2 / 20$ \\
\hline 1 & 4000 & 6 & $20 / 20$ & 72 & $20 / 20$ & $2 / 20$ \\
\hline 2 & 4000 & 6 & $20 / 20$ & 48 & $20 / 20$ & $1 / 20$ \\
\hline 1 & 4000 & 6 & $20 / 20$ & 24 & $14 / 20$ & $2 / 20$ \\
\hline 2 & 2000 & 6 & $20 / 20$ & 48 & $16 / 20$ & $4 / 20$ \\
\hline 2 & 1000 & 6 & $20 / 20$ & 48 & $1 / 20$ & $2 / 20$ \\
\hline 2 & 100 & 6 & $20 / 20$ & 48 & $0 / 20$ & $3 / 20$ \\
\hline 1 & 50 & 6 & $20 / 20$ & 48 & $1 / 20$ & $1 / 20$ \\
\hline 1 & 25 & 6 & $20 / 20$ & 48 & $3 / 20$ & $5 / 20$ \\
\hline 1 & 1000 & $6(2$ days $)$ & $24 / 24$ & 48 & $6 / 24$ & $4 / 24$ \\
\hline 1 & 400 & $6(5$ days $)$ & $24 / 24$ & 48 & $5 / 24$ & $5 / 24$ \\
\hline 1 & 50 & 8 (5 days $)$ & $24 / 24$ & 48 & $6 / 24$ & $5 / 24$ \\
\hline 1 & 25 & 8 ( 5 days) & $24 / 24$ & 48 & $4 / 24$ & $4 / 24$ \\
\hline 1 & $3.25 \mathrm{mg} / \mathrm{g}$ & Oral & $19 / 20$ & 48 & $19 / 19$ & $0 / 20$ \\
\hline 1 & $\begin{array}{c}0 \\
\text { (Fasted, } 48 \mathrm{hr} \text { ) }\end{array}$ & - & $20 / 20$ & 48 & $0 / 20$ & $2 / 20$ \\
\hline
\end{tabular}

- Number showing survival/number tested. 
The effects of exposure to $\mathrm{CCl}_{4}$ on the development of tolerance to subsequent lethal doses are summarized in Table 1.

Rats preexposed to $6000 \mathrm{ppm}, 4000 \mathrm{ppm}$, and those given an oral $3.25 \mathrm{mg} / \mathrm{g} \mathrm{CCl}_{4}$ dose, 48 hours thereafter all developed tolerance to a normally lethal $\mathrm{CCl}_{4}$ exposure. Only partial tolerance was developed (14/20) when rats were preexposed to $4000 \mathrm{ppm}$ and after $24 \mathrm{hr}$ reexposed to a normally lethal level of $\mathrm{CCl}_{4}$. Similarly, partial tolerance $(16 / 20)$ developed when rats were preexposed to $2000 \mathrm{ppm}$ and after $48 \mathrm{hr}$ reexposed to a normally lethal dose. No tolerance was developed when rats were preexposed to $\mathrm{CCl}_{4}$ concentrations below $2000 \mathrm{ppm}$, whether after a single acute 6-hour preexposure or after extended 2-5 days preexposures.

A complete protective effect was still evident $96 \mathrm{hr}$ after preexposure to $4000 \mathrm{ppm}$ for $6 \mathrm{hr}$ and $120 \mathrm{hr}$ after a $6-\mathrm{hr}$ preexposure to $6000 \mathrm{ppm}$.

Animals also were protected (19/20) against a normally lethal exposure to $\mathrm{CCl}_{4}$ when preexposed to $4000 \mathrm{ppm}$ of $\mathrm{CHCl}_{3}$ for $1 \mathrm{hr}$, and against a normally lethal dose of $\mathrm{CHCl}_{3}$ (4200 ppm for $5 \mathrm{hr}$ ) when they were preexposed to $4000 \mathrm{ppm}$ of $\mathrm{CCl}_{4}$ for $6 \mathrm{hr}$. Again, only partial protection (13/20) was observed when rats were preexposed to 2000 $\mathrm{ppm}$ of $\mathrm{CCl}_{4}$ for $6 \mathrm{hr}$ and $48 \mathrm{hr}$ later reexposed to a normally lethal dose of $\mathrm{CHCl}_{3}$.

\section{Liver Weight}

Slight decrease in liver weight was noted only immediately after the 6-hr single $\mathrm{CCl}_{4}$ exposures and marked decrease only in fasted rat liver. No changes in liver weight were noted in rats receiving the two $\mathrm{CCl}_{4}$ exposures.

\section{Blood Clotting Time and Serum Bilirubin}

Blood clotting times and serum bilirubin levels of rats exposed to $\mathrm{CCl}_{4}$ or fasted and subsequently exposed to $\mathrm{CCl}_{4}$ are presented in Table 2 .

TABLE 2

Blood Clotting Time and Serum Bilirubin of Rats EXPOSED TO CARBON TETRACHLORIDE

\begin{tabular}{|c|c|c|c|c|c|}
\hline \multirow[b]{2}{*}{$\mathrm{CCl}_{4} \mathrm{ppm}$} & \multirow{2}{*}{$\begin{array}{l}\text { No. of } \\
\text { rats }\end{array}$} & \multirow{2}{*}{$\begin{array}{c}\text { Sacrificed } \\
\text { hours after } \\
\text { treatment }\end{array}$} & \multicolumn{2}{|c|}{ Serum bilirubin $(\mathrm{mg} / 100 \mathrm{ml})$} & \multirow{2}{*}{$\begin{array}{l}\text { Blood clotting } \\
\text { time (min) }\end{array}$} \\
\hline & & & Direct & Total & \\
\hline 0 & 5 & 一 & $0.03 \pm 0.01^{a}$ & $0.32 \pm 0.16^{a}$ & $2.2(2.0-2.5)^{b}$ \\
\hline $4000^{c}$ & 5 & 24 & $0.14 \pm 0.03^{e}$ & $1.02 \pm 0.40^{e}$ & $1.7(1.0-2.5)$ \\
\hline $7500^{d}$ & 5 & 24 & $2.09 \pm 0.15^{e}$ & $3.79 \pm 0.21^{e}$ & $21.0(20.0-22.0)$ \\
\hline $\begin{array}{l}4000^{c}+7500^{d} \\
0\end{array}$ & 5 & 24 & $0.43 \pm 0.07^{e}$ & $0.89 \pm 0.14^{e}$ & $2.4(2.3-2.5)$ \\
\hline (Fasted, $48 \mathrm{hr}$ ) & 5 & 24 & $0.09 \pm 0.04$ & $0.23 \pm 0.13$ & $2.1(1.6-2.5)$ \\
\hline $\begin{array}{l}7500^{d} \\
\text { (Fasted, } 48 \mathrm{hr} \text { ) }\end{array}$ & 5 & 24 & $2.52 \pm 0.36^{e}$ & $6.00 \pm 0.68^{e}$ & $44.0(33.5-55.0)$ \\
\hline
\end{tabular}

${ }^{a}$ Mean \pm standard deviation.

${ }^{b}$ Ranges in parentheses.

${ }^{c}$ Exposed for $6 \mathrm{hr}$.

${ }^{d}$ Exposed for $5.5 \mathrm{hr}$.

e Significantly different from normal, $\boldsymbol{P}<0.01$. 
DAMBRAUSKAS AND CORNISH

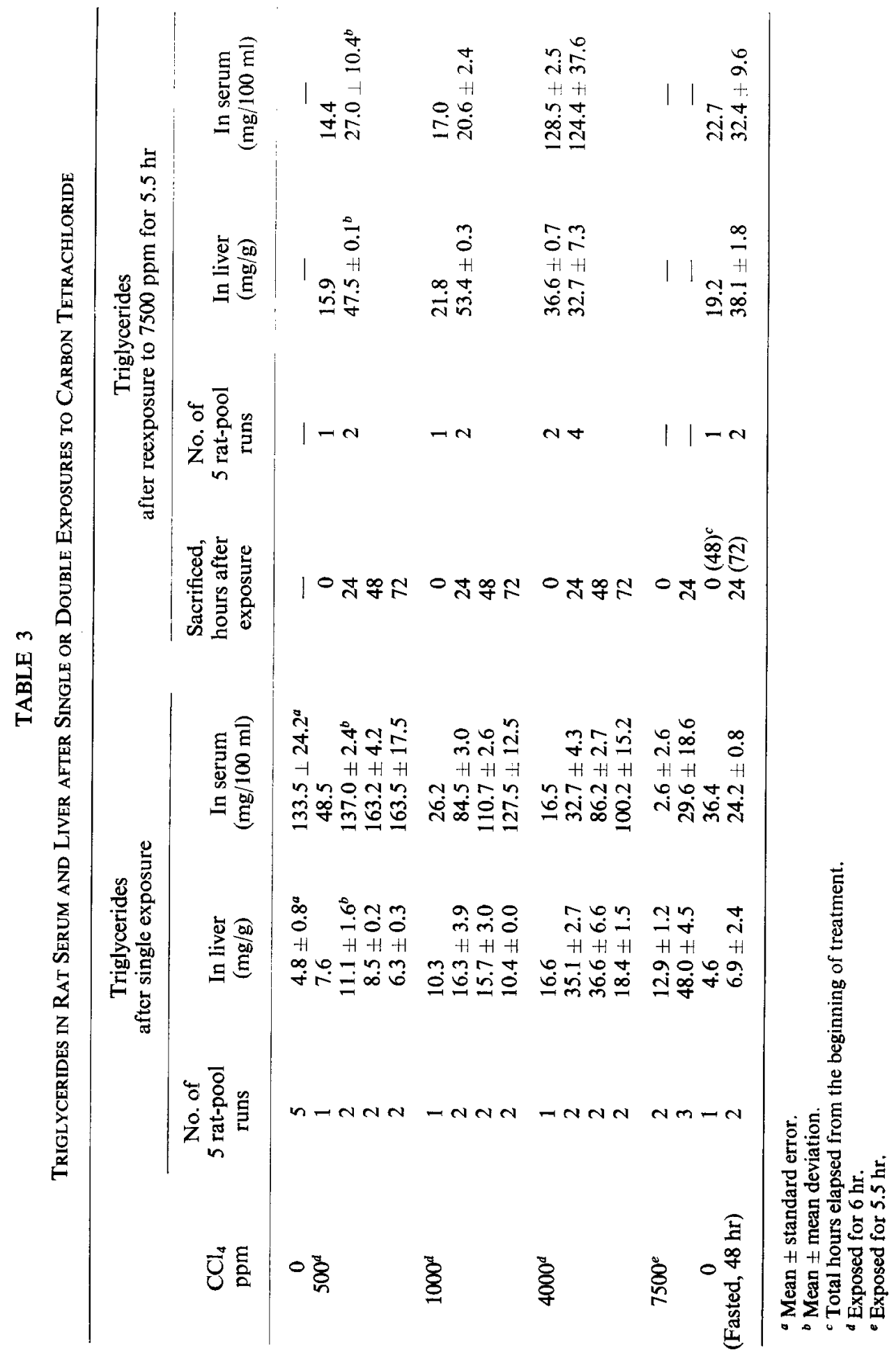


Fasting or exposure of animals to $4000 \mathrm{ppm}$ of $\mathrm{CCl}_{4}$ had no effect on blood clotting time as shown in Table 2. Blood clotting time was prolonged only when rats were killed $24 \mathrm{hr}$ after exposure to $7500 \mathrm{ppm}$, whether they were fasted or not. Animals preexposed to 4000 ppm of $\mathrm{CCl}_{4}$ and subsequently exposed to $7500 \mathrm{ppm}$, had normal blood clotting times.

Twenty-four hours after exposure to $\mathrm{CCl}_{4}$, all bilirubin levels were significantly elevated. However, rats receiving a single exposure to $7500 \mathrm{ppm}$ had bilirubin levels 4 to 5 times higher than those of rats exposed to $4000 \mathrm{ppm}$ for 6 and $48 \mathrm{hr}$ later reexposed to $7500 \mathrm{ppm}$. A 48-hr fasting period had no effect on serum bilirubin levels. Fasted animals, however, appeared to be more susceptible to $\mathrm{CCl}_{4}$ exposure as evidenced by the enhanced elevations of both direct and total serum bilirubin levels when animals were exposed to $7500 \mathrm{ppm}$ after $48 \mathrm{hr}$ of fasting.

\section{Serum and Liver Triglycerides}

Serum and liver triglyceride levels were determined in fasted rats and in those receiving single or double exposures to $\mathrm{CCl}_{4}$. The results are presented in Table 3 .

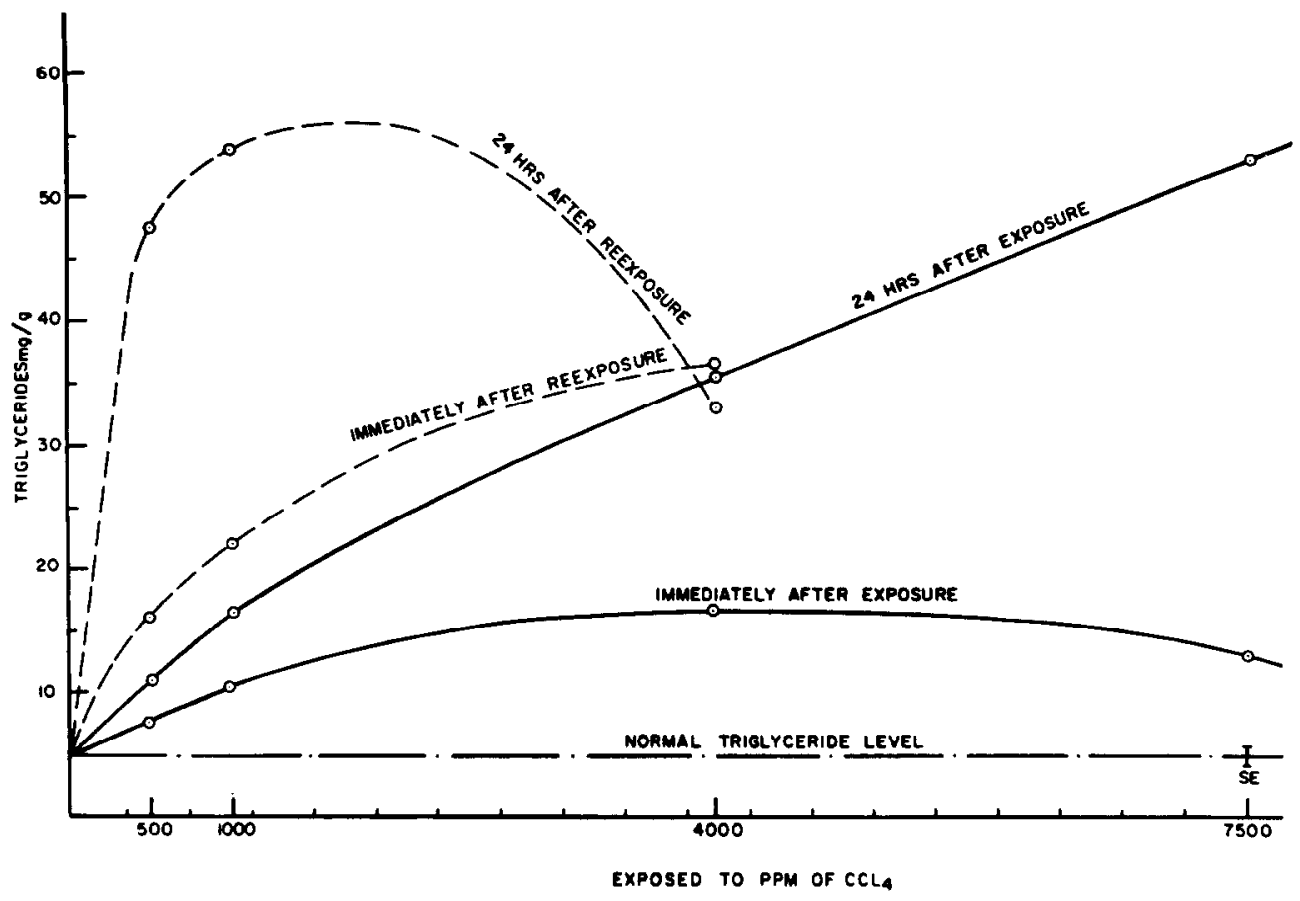

FIG. 2. Liver triglyceride levels of rats receiving single and double $\mathrm{CCl}_{4}$ exposures. Solid line indicates single, and broken line double, exposure.

In general, liver triglyceride concentrations of rats exposed to various $\mathrm{CCl}_{4}$ vapor concentrations were increased and serum triglycerides decreased progressively with increasing exposure concentrations. No changes in liver triglycerides were found in 48-hr fasted rats. After reexposure, changes in serum and liver triglyceride concentrations were somewhat greater than after the single exposure, with the exception of the rats preexposed to $4000 \mathrm{ppm}$ and $48 \mathrm{hr}$ later reexposed to $7500 \mathrm{ppm}$. In these animals, serum triglycerides were normal. 
The liver and serum triglyceride levels in rats preexposed to $\mathrm{CCl}_{4}$ concentrations as indicated in Table 3 and $48 \mathrm{hr}$ later reexposed to $7500 \mathrm{ppm}$ are illustrated graphically in Figs. 2 and 3.

Twenty-four hours after single $500-7500 \mathrm{ppm} \mathrm{CCl}_{4}$ exposures, the increase in rat liver triglycerides (Fig. 2) was almost linear, varying directly with the dose. When rats were exposed to 500 or $1000 \mathrm{ppm}$ for $6 \mathrm{hr}$ (nonprotective dose) and after $48 \mathrm{hr}$ were reexposed to $7500 \mathrm{ppm}$ for $5.5 \mathrm{hr}$ (lethal dose), liver triglyceride values increased sharply,

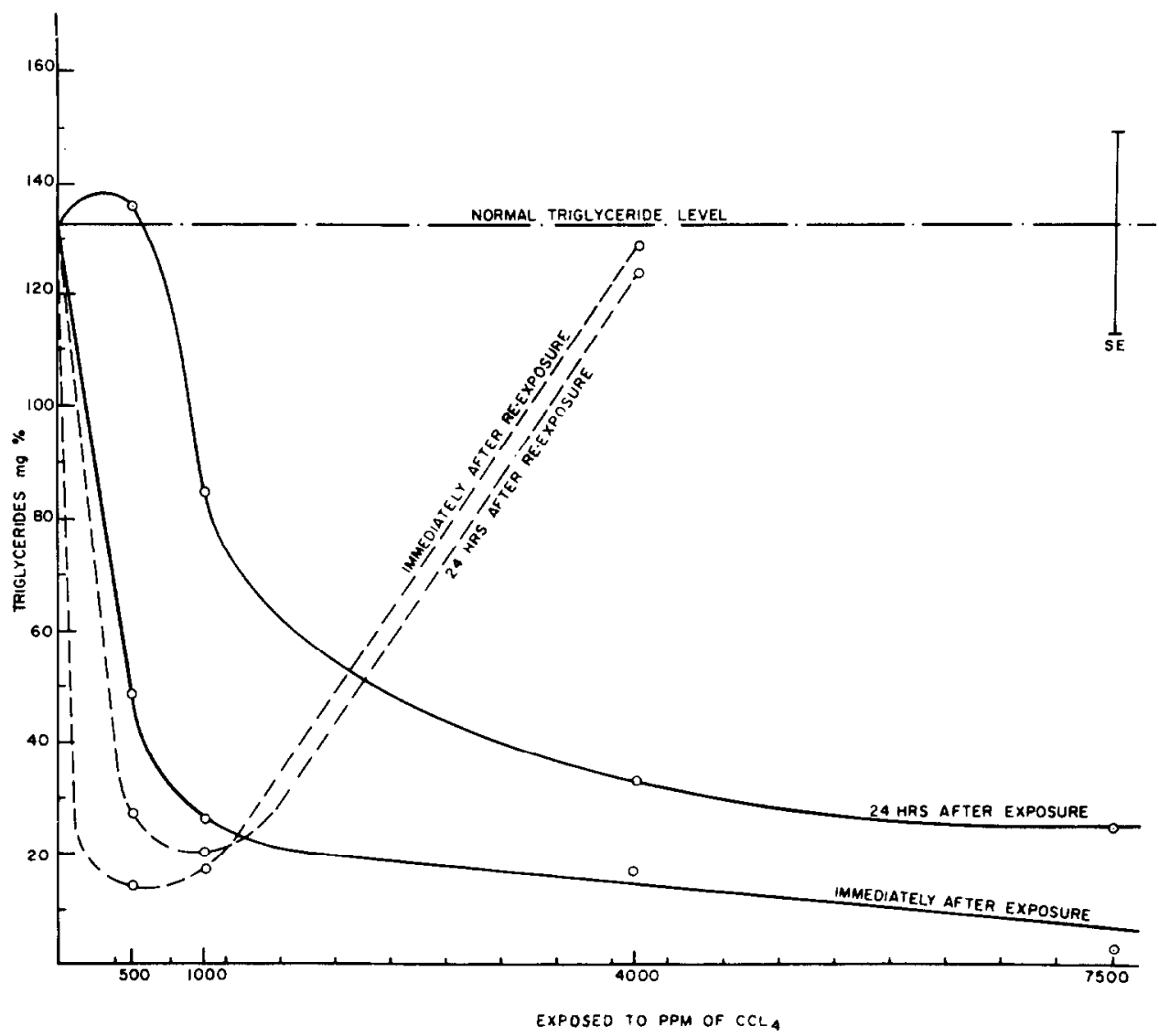

Frg. 3. Serum triglyceride levels of rats receiving single and double $\mathrm{CCl}_{4}$ exposures. Solid line indicates single, and broken line double, exposure.

as compared to values after single exposures. However, liver triglycerides of rats exposed to $4000 \mathrm{ppm}$ (protective dose) and reexposed to $7500 \mathrm{ppm}$ remained at the same levels as in rats receiving a single $4000 \mathrm{ppm}$ exposure.

Serum triglyceride changes in rats receiving protective and nonprotective exposures to $\mathrm{CCl}_{4}$ were the opposite of those found in liver (Fig. 3). Immediately and $24 \mathrm{hr}$ after single 500-7500 ppm exposures, triglyceride levels decreased progressively with increased exposure concentration. A still further decrease in serum triglycerides was found in rats exposed to $500-1000 \mathrm{ppm}$ and $48 \mathrm{hr}$ later reexposed to $7500 \mathrm{ppm}$. However, 
in rats exposed to $4000 \mathrm{ppm}$ and then reexposed to $7500 \mathrm{ppm}$, serum triglycerides increased and regained their normal levels.

\section{Carbon Tetrachloride and Chloroform in Rat Tissues}

Carbon tetrachloride was detectable in the tissues of rats after exposure to this compound (Fig. 4). In addition, chloroform was also found in the liver of exposed animals.
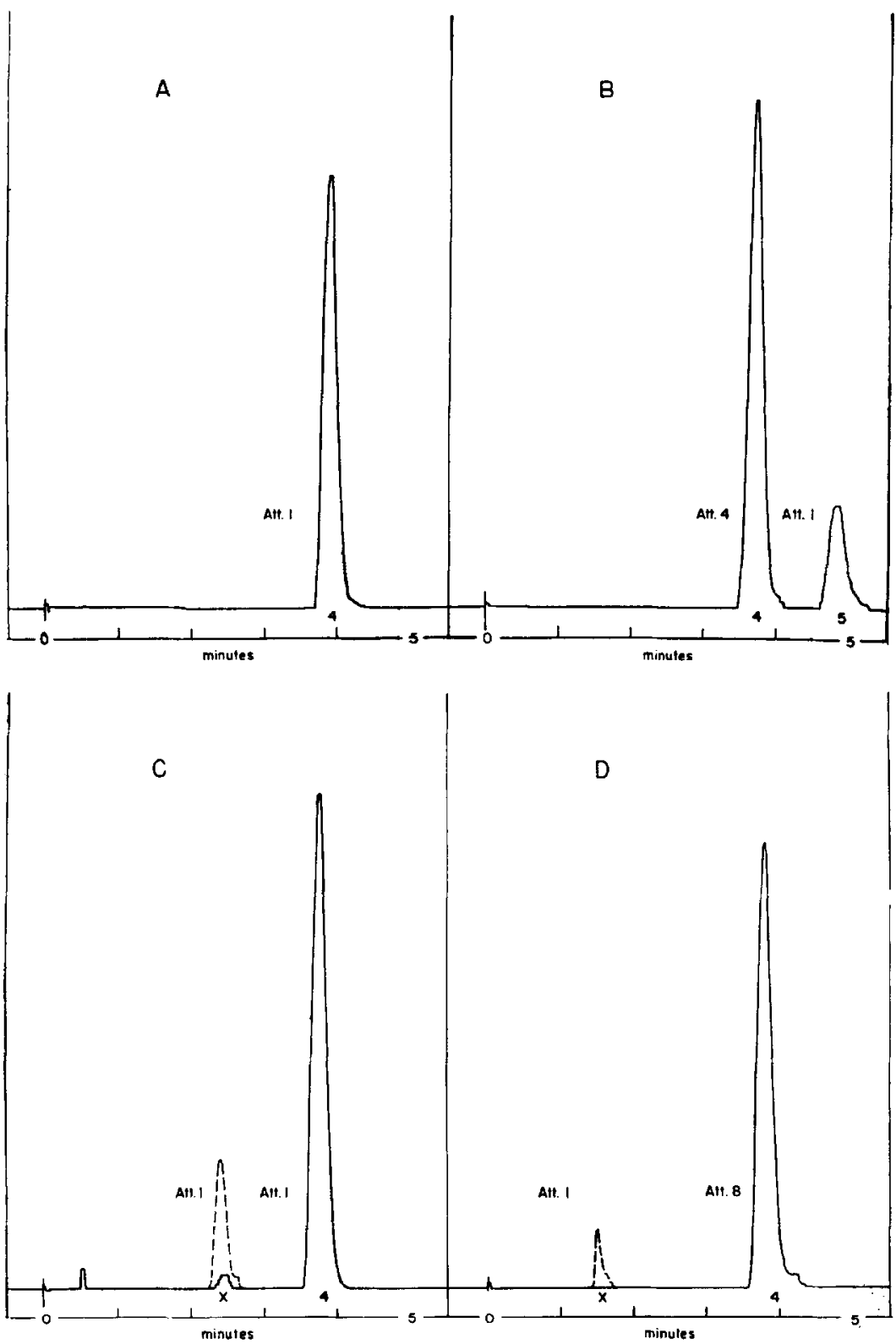

Fig. 4. Gas chromatogram of tissue after exposure to $4000 \mathrm{ppm}$ of $\mathrm{CCl}_{4}$. A indicates recovery of $\mathrm{CCl}_{4}$ from blood; $\mathrm{B}$, recovery of $\mathrm{CCl}_{4}$ and $\mathrm{CHCl}_{3}$ from liver; $\mathrm{C}$, recovery of $\mathrm{CCl}_{4}$ from kidney, $\mathrm{D}$, recovery of $\mathrm{CCl}_{4}$ from fat. Broken line peaks indicate an occasional appearance of unidentified components. 
Figure 4 shows typical gas chromatograms of blood (A), liver (B), kidney (C), and fat (D) of animals exposed to $4000 \mathrm{ppm}$ of $\mathrm{CCl}_{4}$ and sacrificed immediately after exposure. Carbon tetrachloride is identified by peak 4 and chloroform by peak 5 . An unidentified peak (broken line) appeared occasionally on chromatograms of kidney and fat of both control and exposed rats.

The concentration of $\mathrm{CCl}_{4}$ and $\mathrm{CHCl}_{3}$ found in rat organs is presented in Table 4 .

TABLE 4

Recovery of Carbon Tetrachloride and Chloroform from Rat Tissues Immediately AFTER EXPOSURE TO CARBON TETRACHLORIDE

\begin{tabular}{|c|c|c|c|c|c|c|}
\hline \multirow[b]{2}{*}{$\begin{array}{c}\mathrm{CCl}_{4} \\
(\mathrm{ppm})\end{array}$} & \multirow{2}{*}{$\begin{array}{l}\text { Blood } \\
\mathrm{CCl}_{4} \\
(\mu \mathrm{g} / \mathrm{g})\end{array}$} & \multicolumn{2}{|c|}{ Liver } & \multirow{2}{*}{$\begin{array}{l}\text { Kidney } \\
\underset{(\mu \mathrm{g} / \mathrm{g})}{\mathrm{CCl}_{4}}\end{array}$} & \multirow{2}{*}{$\begin{array}{c}\text { Fat } \\
\mathrm{CCl}_{4} \\
(\mu \mathrm{g} / \mathrm{g})\end{array}$} & \multirow{2}{*}{$\begin{array}{c}\text { Brain } \\
\mathrm{CCl}_{4} \\
(\mu \mathrm{g} / \mathrm{g})\end{array}$} \\
\hline & & $\begin{array}{c}\mathrm{CCl}_{4} \\
(\mu \mathrm{g} / \mathrm{g})\end{array}$ & $\underset{(\mu \mathrm{g} / \mathrm{g})}{\mathrm{CHCl}_{3}}$ & & & \\
\hline $4000^{a}$ & $\begin{array}{l}40 \\
75 \\
82 \\
36 \\
85\end{array}$ & $\begin{array}{r}146 \\
129 \\
135 \\
87 \\
182\end{array}$ & $\begin{array}{r}9 \\
10 \\
12 \\
7 \\
9\end{array}$ & $\begin{array}{l}219 \\
228 \\
277 \\
229 \\
213\end{array}$ & $\begin{array}{l}1200 \\
1023 \\
2100 \\
1885 \\
2162\end{array}$ & $\begin{array}{l}426 \\
319 \\
440 \\
442 \\
-\end{array}$ \\
\hline Mean \pm SD & $\begin{array}{r}63.6^{c} \\
\pm 23.7\end{array}$ & $\begin{array}{r}135.8^{c} \\
\pm 34.2\end{array}$ & $\begin{array}{c}9.6 \\
\pm 1.80\end{array}$ & $\begin{array}{c}233.2^{c} \\
\pm 25.4\end{array}$ & $\begin{array}{r}1674.0 \\
\pm 527.4\end{array}$ & $\begin{array}{c}406.7^{c} \\
\pm 58.9\end{array}$ \\
\hline $7500^{b}$ & $\begin{array}{l}115 \\
129 \\
116 \\
157 \\
139\end{array}$ & $\begin{array}{l}510 \\
397 \\
397 \\
428 \\
450\end{array}$ & $\begin{array}{r}11 \\
11 \\
10 \\
11 \\
8\end{array}$ & $\begin{array}{l}341 \\
458 \\
462 \\
455 \\
384\end{array}$ & $\begin{array}{l}1795 \\
1715 \\
1750 \\
1575 \\
2445\end{array}$ & $\begin{array}{r}970 \\
980 \\
1070 \\
1080 \\
-\end{array}$ \\
\hline Mean \pm SD & $\begin{array}{c}131.2^{c} \\
+17.5\end{array}$ & $\begin{array}{r}436.4^{c} \\
+46.8\end{array}$ & $\begin{array}{c}10.2 \\
\pm 1.30\end{array}$ & $\begin{array}{r}420.0 \\
+54.7\end{array}$ & $\begin{array}{r}1856.0 \\
\pm 339.4\end{array}$ & $\begin{array}{r}1025.0 \\
+58.0\end{array}$ \\
\hline $\begin{array}{c}4000^{a} \\
+ \\
7500^{b}\end{array}$ & $\begin{array}{l}157 \\
167 \\
180 \\
173 \\
187\end{array}$ & $\begin{array}{l}635 \\
478 \\
786 \\
634 \\
647\end{array}$ & $\begin{array}{l}7 \\
8 \\
8 \\
7 \\
5\end{array}$ & $\begin{array}{l}490 \\
497 \\
451 \\
584 \\
408\end{array}$ & $\begin{array}{l}3620 \\
4980 \\
5930 \\
5180 \\
5900\end{array}$ & $\begin{array}{r}1010 \\
940 \\
985 \\
835 \\
-\end{array}$ \\
\hline Mean $\pm \mathbf{S D}$ & $\begin{array}{r}172.8^{c} \\
\pm 11.6\end{array}$ & $\begin{array}{r}636.0^{c} \\
\pm 109.8\end{array}$ & $\begin{array}{r}7.0^{c} \\
\pm 1.23\end{array}$ & $\begin{array}{r}486.0 \\
\pm 65.3\end{array}$ & $\begin{array}{c}5122.0^{c} \\
\pm 940.4\end{array}$ & $\begin{array}{r}942.5 \\
\pm 77.3\end{array}$ \\
\hline
\end{tabular}

${ }^{a}$ Exposed for $6 \mathrm{hr}$.

${ }^{b}$ Exposed for $5.5 \mathrm{hr}$.

c Significantly different, $P<0.01$.

After exposure to $4000 \mathrm{ppm}, \mathrm{CCl}_{4}$ concentrations in all tissues, except fat, were, as expected, significantly lower than after exposures to $7500 \mathrm{ppm}$ for $5.5 \mathrm{hr}$. In animals exposed to $4000 \mathrm{ppm}$ and reexposed $48 \mathrm{hr}$ later to $7500 \mathrm{ppm}$, the concentration of $\mathrm{CCl}_{4}$ in blood, liver, and fat was significantly higher than in animals receiving a single exposure to $7500 \mathrm{ppm}$ of carbon tetrachloride. The concentration of $\mathrm{CHCl}_{3}$ in the liver of animals previously exposed to $4000 \mathrm{ppm}$ and subsequently reexposed to $7500 \mathrm{ppm}$ of $\mathrm{CCl}_{4}$, although not of great magnitude, was significantly lower than in the animals receiving a single exposure to $7500 \mathrm{ppm}$. 
Since animals receiving a single or double $\mathrm{CCl}_{4}$ exposure might have different rates of absorption, distribution, and excretion of carbon tetrachloride and its metabolites, the concentration of $\mathrm{CCl}_{4}$ and $\mathrm{CHCl}_{3}$ in the whole rat was determined after single and double exposures to $\mathrm{CCl}_{4}$. A composite chromatogram of a series of such determinations is shown in Fig. 5.

The carbon tetrachloride peak (4) and chloroform peak (5) were present on all chromatograms. Peaks marked by $\mathrm{x}$ are unidentified compounds, some of them also

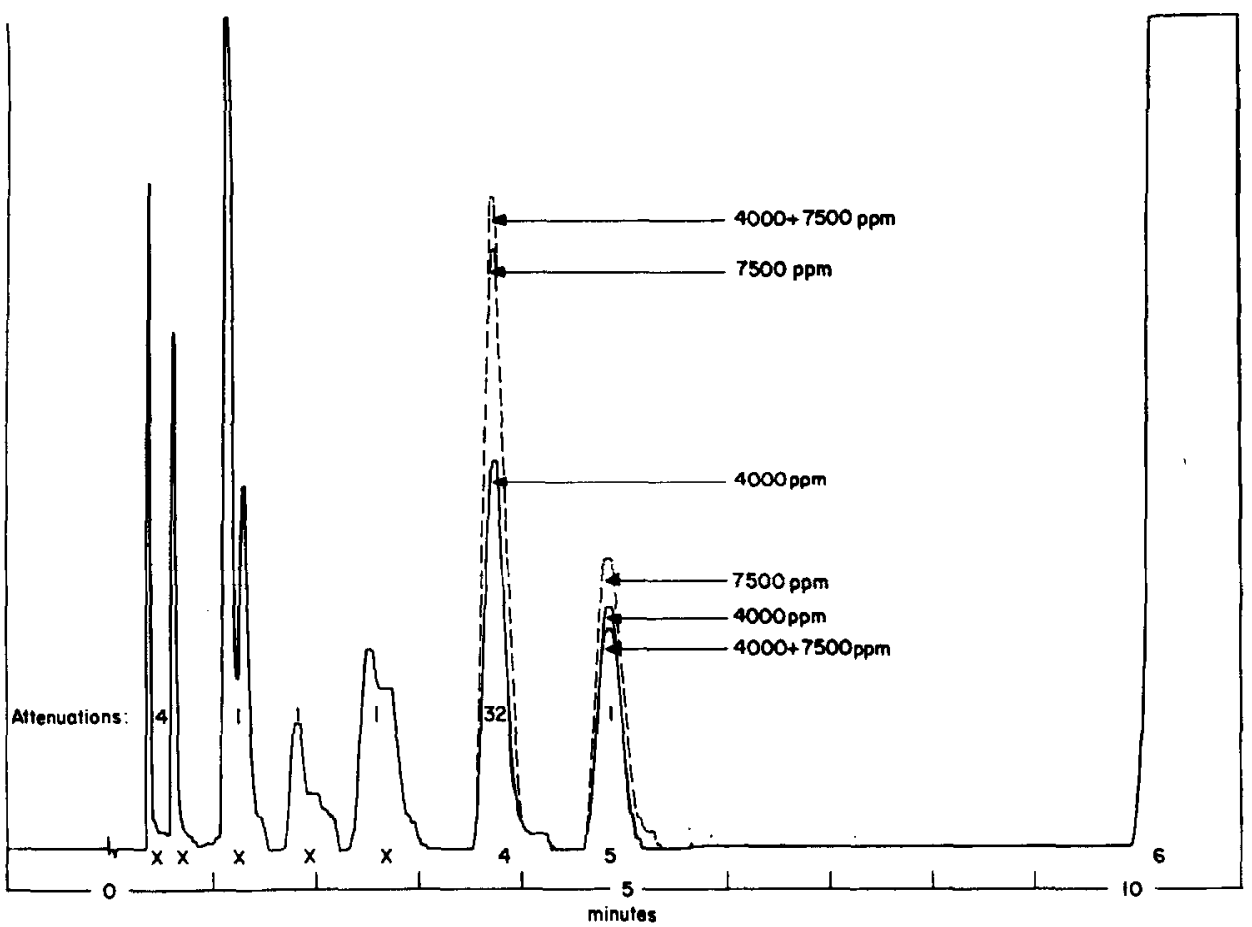

FIG. 5. Gas chromatogram indicating recovery of $\mathrm{CCl}_{4}$ (peak 4) and $\mathrm{CHCl}_{3}$ (peak 5) from whole rat after exposure to $4000 \mathrm{ppm}$ of $\mathrm{CCl}_{4}$. Peaks $\times$ denote unidentified components, some of which also appear in normal rats. Broken line peaks were transposed from other gas chromatograms after corresponding exposures to $\mathrm{CCl}_{4}$.

appearing on chromatograms from normal animals. The recovery of $\mathrm{CCl}_{4}$ and $\mathrm{CHCl}_{3}$ from the whole rat is presented in Table 5 .

Almost double the amount of $\mathrm{CHCl}_{3}$ was found in animals receiving a single 7500 ppm exposure compared to the amount of $\mathrm{CHCl}_{3}$ in animals after two exposures $(4000$ and $7500 \mathrm{ppm}$ ), whereas the total amounts of $\mathrm{CCl}_{4}$ in these two groups of animals were quite comparable. The amount of $\mathrm{CHCl}_{3}$ per gram of body weight was approximately the same, $1.23 \pm 0.16$ and $1.37 \pm 0.07 \mu \mathrm{g} / \mathrm{g}$, in the two groups of rats that survived, i.e., after a single $4000 \mathrm{ppm}$ and double $(4000+7500 \mathrm{ppm})$ exposures, respectively.

The effect of preexposure to $\mathrm{CCl}_{4}$ on the conversion of $\mathrm{CCl}_{4}$ to $\mathrm{CHCl}_{3}$ in vitro was the same as in vivo; normal rat liver in vitro produced $13.7 \pm 1.9 \mu \mathrm{g} \mathrm{CHCl}_{3}$ per gram of liver, compared to $3.5 \pm 1.2 \mu \mathrm{g} / \mathrm{g}$ produced by liver of rats sacrificed $48 \mathrm{hr}$ after preexposure to $4000 \mathrm{ppm}$ of $\mathrm{CCl}_{4}$. 
TABLE 5

Recovery of Carbon Tetrachloride and Chloroform from the Whole Rat Immediately after EXPOSURE to Carbon Tetrachloride

\begin{tabular}{|c|c|c|c|c|c|}
\hline \multirow[b]{2}{*}{$\begin{array}{l}\mathrm{CCl}_{4} \\
(\mathrm{ppm})\end{array}$} & \multirow{2}{*}{$\begin{array}{c}\text { Rat } \\
\text { weight } \\
\text { (g) }\end{array}$} & \multicolumn{2}{|c|}{$\mathrm{CCl}_{4}$} & \multicolumn{2}{|c|}{$\mathrm{CHCl}_{3}$} \\
\hline & & $\begin{array}{l}\text { Total } \\
(\mu \mathrm{g})\end{array}$ & $\begin{array}{l}\text { Per gram } \\
(\mu \mathrm{g})\end{array}$ & $\begin{array}{c}\text { Total } \\
(\mu \mathrm{g})\end{array}$ & $\begin{array}{l}\text { Per gram } \\
\quad(\mu \mathrm{g})\end{array}$ \\
\hline $4000^{a}$ & $\begin{array}{l}219 \\
200 \\
228 \\
194\end{array}$ & $\begin{array}{l}14363 \\
16220 \\
12704 \\
12540\end{array}$ & $\begin{array}{l}66 \\
81 \\
56 \\
66\end{array}$ & $\begin{array}{l}292 \\
278 \\
236 \\
222\end{array}$ & $\begin{array}{l}1.33 \\
1.39 \\
1.04 \\
1.14\end{array}$ \\
\hline Mean \pm SD & 210 & $\begin{array}{c}14031^{c} \\
\pm 1641\end{array}$ & $\begin{aligned} & 67.2^{c} \\
+ & 10.5\end{aligned}$ & $\begin{array}{r}257.0 \\
\pm 33.3\end{array}$ & $\begin{array}{r}1.23 \\
+0.16\end{array}$ \\
\hline $7500^{b}$ & $\begin{array}{l}220 \\
191 \\
235 \\
226\end{array}$ & $\begin{array}{l}32700 \\
28400 \\
28255 \\
30310\end{array}$ & $\begin{array}{l}149 \\
149 \\
120 \\
134\end{array}$ & $\begin{array}{l}507 \\
413 \\
408 \\
422\end{array}$ & $\begin{array}{l}2.30 \\
2.16 \\
1.74 \\
1.87\end{array}$ \\
\hline Mean $\pm \mathbf{S D}$ & 218 & $\begin{array}{r}29916 \\
+2078\end{array}$ & $\begin{array}{l}137.9 \\
\pm 13.6\end{array}$ & $\begin{array}{c}437.5^{c} \\
\pm 46.7\end{array}$ & $\begin{aligned} & 2.02^{c} \\
\pm & 0.26\end{aligned}$ \\
\hline $4000^{a}+7500^{b}$ & $\begin{array}{l}189 \\
205 \\
199 \\
203\end{array}$ & $\begin{array}{l}30220 \\
29400 \\
33760 \\
24150\end{array}$ & $\begin{array}{l}160 \\
143 \\
170 \\
119\end{array}$ & $\begin{array}{l}275 \\
274 \\
258 \\
279\end{array}$ & $\begin{array}{l}1.46 \\
1.34 \\
1.30 \\
1.37\end{array}$ \\
\hline Mean $\pm \mathbf{S D}$ & 198 & $\begin{array}{r}29382 \\
\pm 3968\end{array}$ & $\begin{array}{r}148.0 \\
\pm 22.1\end{array}$ & $\begin{array}{l}271.5 \\
\pm 9.3\end{array}$ & $\begin{array}{r}1.37 \\
\pm 0.07\end{array}$ \\
\hline
\end{tabular}

${ }^{a}$ Exposed for $6 \mathrm{hr}$.

${ }^{b}$ Exposed for $5.5 \mathrm{hr}$.

c Significantly different, $P<0.01$.

\section{Histopathology}

A summary of the histopathologic findings is given below.

The lungs of exposed animals were comparable to those of control animals.

The following morphologic changes were found in liver:

1. At $24 \mathrm{hr}$ after exposure to $4000 \mathrm{ppm}$ for $6 \mathrm{hr}$ : moderate to extensive centrilobular necrosis with infiltrative mononuclear cells; the necrotic areas were circumscribed by large vacuolated cells; there was extensive to severe lipid infiltration around the necrotic areas, several vacuolated areas which did not stain for fat.

2. At $48 \mathrm{hr}$ after exposure to $4000 \mathrm{ppm}$ for $6 \mathrm{hr}$ : there was moderate centrilobular necrosis with marked vacuolization of adjacent parenchymal cells; slight to moderate lipid infiltration most pronounced around the necrotic areas.

3. At $24 \mathrm{hr}$ after exposure to $7500 \mathrm{ppm}$ for $5.5 \mathrm{hr}$ : there was centrilobular cloudy swelling of hepatic parenchymal cells, hyaline and hydropic degeneration; in some rats there was nuclear pyknosis and karyorrhexis of hepatic parenchymal cells but no necrosis; moderate lipid infiltration most pronounced in periportal areas.

4. At $24 \mathrm{hr}$ after double exposure $(4000 \mathrm{ppm}$ for $6 \mathrm{hr}$ then $48 \mathrm{hr}$ later exposed to 7500 ppm for $5.5 \mathrm{hr}$ ): there was slight to moderate centrilobular necrosis, widespread hydropic 
degeneration and cloudy swelling of parenchymal cells, moderate lipid infiltration being most extensive in periportal areas.

\section{DISCUSSION}

Most animals died within $24-48 \mathrm{hr}$ when exposed to $7500 \mathrm{ppm}$ of $\mathrm{CCl}_{4}$ for $5.5 \mathrm{hr}$ or when preexposed to $\mathrm{CCl}_{4}$ concentrations below $2000 \mathrm{ppm}$ for $6 \mathrm{hr}$ and $48 \mathrm{hr}$ later reexposed to $7500 \mathrm{ppm}$. Twenty-four hours after exposure these animals were obviously sick, with shabby fur, slow movement, and no food consumption.

Animals exposed to 4000 and $6000 \mathrm{ppm}$ of $\mathrm{CCl}_{4}$, or given $3.25 \mathrm{mg} / \mathrm{g}$ orally, developed tolerance and were protected against the acute toxicity of $\mathrm{CCl}_{4}$ when reexposed $48 \mathrm{hr}$ later to a normally lethal dose. These animals retained a healthy normal appearance and their food consumption was about $50 \%$ of normal. Though $\mathrm{CCl}_{4}$-exposed rats did not eat as much as control rats, fasting apparently was not involved in protection since 48 $\mathrm{hr}$ fasted rats were not protected against the same lethal exposure to $\mathrm{CCl}_{4}$.

For tolerance development and protection against a lethal dose of $\mathrm{CCl}_{4}$, preexposure concentration (sufficient insult) and a minimum time interval (approximately $48 \mathrm{hr}$ ) prior to reexposure were the essential prerequisites.

Serum bilirubin concentration and blood clotting time seemed to parallel the degree of protection. Twenty-four hours after exposure to $7500 \mathrm{ppm}$ for $5.5 \mathrm{hr}$, rats had markedly clevated bilirubin levels as well as greatly prolonged clotting times. When animals were pretreated with $4000 \mathrm{ppm}$ of $\mathrm{CCl}_{4} 48 \mathrm{hr}$ prior to the $7500 \mathrm{ppm}$ exposure, bilirubin levels were only slightly elevated and blood clotting times were normal. Thus tolerance development was indicated not only in terms of decreased mortality, but also in biochemical parameters.

Development of fatty liver is a characteristic phenomenon associated with $\mathrm{CCl}_{4}$ toxicity. Decreased serum triglyceride levels and concomitant elevations of liver triglycerides in animals treated with $\mathrm{CCl}_{4}$ have been reported by a number of investigators (Heimberg et al., 1962; Lombardi, 1965). During the investigation described in this paper, increase in liver triglycerides and a concomitant decrease in serum triglycerides were in direct correlation with the degree of exposure except in rats doubly exposed to $\mathrm{CCl}_{4}$.

According to one recently advanced hypothesis, the earliest morphologic changes in the hepatic cell after $\mathrm{CCl}_{4}$ intoxication, are swelling and disruption of the endoplasmic reticulum resulting in inhibition of protein synthesis. The inhibition of protein synthesis would prevent the formation and release of glycerides as lipoprotein complexes (Smuckler et al., 1961; Seakins and Robinson, 1963; Lombardi, 1965).

In our studies, progressively higher $\mathrm{CCl}_{4}$ exposures $(500-7500 \mathrm{ppm})$ paralleled by greater accumulation of triglycerides in liver and concomitant decreases in serum might reflect the degree of the initial biochemical lesion and resultant greater depression of protein synthesis. The same, but more pronounced, triglyceride departure from the normals were observed after previously exposed rats were reexposed to $7500 \mathrm{ppm}$, with the exception of rats previously exposed to $4000 \mathrm{ppm}$. After exposure to $7500 \mathrm{ppm}$ of $\mathrm{CCl}_{4}$, liver triglycerides reached the highest level, $48.0 \mathrm{mg} / \mathrm{g}$ at $24 \mathrm{hr}$, and serum triglycerides the lowest level, $2.6 \mathrm{mg} / 100 \mathrm{ml}$ immediately after exposure. At the same time, rats previously exposed to $4000 \mathrm{ppm}$ and after $48 \mathrm{hr}$ reexposed to $7500 \mathrm{ppm}$ had normal serum triglyceride levels, $128 \mathrm{mg} / 100 \mathrm{ml}$, while liver triglyceride levels, though 
elevated $(32 \mathrm{mg} / \mathrm{g})$, were about the same as after a single exposure to $4000 \mathrm{ppm}$ (35 mg/100 ml).

The histopathologic findings in the various groups of animals do not appear to relate directly to the protection resulting from preexposure.

The protection afforded by pretreatment with carbon tetrachloride is apparently different from the tolerance developed to ozone as reported by Stokinger (1965), where the development of lung edema appeared to be a prerequisite for protection. Though lung irritation may be produced by high levels of $\mathrm{CCl}_{4}$ exposure, there was no histologic evidence that such occurred in the present studies. In addition, the protective mechanism was evoked even when the first contact with $\mathrm{CCl}_{4}$ was by the oral route.

Microscopic examination of the liver in several series of rats showed that in animals sacrificed $24 \mathrm{hr}$ after receiving a singlc exposurc to cither $4000 \mathrm{ppm}(6 \mathrm{hr})$ or $7500 \mathrm{ppm}$ $(5.5 \mathrm{hr})$, moderate centrilobular necrosis was evident only in the group exposed to $4000 \mathrm{ppm}$. Those animals exposed to $7500 \mathrm{ppm}$ of $\mathrm{CCl}_{4}$ in general showed cellular changes characteristic of earlier stages of degeneration including pronounced vacuolization of periportal parenchymal cells and some scattered pyknosis. The reexposure to $7500 \mathrm{ppm}$ of rats previously exposed to $4000 \mathrm{ppm}$ of $\mathrm{CCl}_{4}$ did not induce significant additional morphologic changes in liver when compared to animals sacrificed $48 \mathrm{hr}$ after a single $4000 \mathrm{ppm}$ exposure. However, animals exposed to $7500 \mathrm{ppm}$ died, and those exposed to 4000 and $7500 \mathrm{ppm}$ survived. This is consistent with the hypothesis that the initial effect of $\mathrm{CCl}_{4}$ on the liver is the induction of a biochemical lesion (Brauer et al., 1961) and with the hypothesis that morphologic and functional liver changes are the results of the homolytic cleavage processes of carbon tetrachloride metabolism in the liver cells (Recknagel and Goshal, 1966; Butler, 1961).

Carbon tetrachloride concentrations in the various tissues did not appear to have a direct bearing on mortality. Rats protected by previous exposures to $\mathrm{CCl}_{4}$ had consistently lower tissue levels of $\mathrm{CHCl}_{3}$ than rats receiving a single lethal exposure to $\mathrm{CCl}_{4}$. This suggested that the rate of conversion of $\mathrm{CCl}_{4}$ to $\mathrm{CHCl}_{3}$ was considerably depressed in the protected animals at the time of the second exposure.

Butler (1961) and Paul and Rubinstein (1963) reported the partial conversion of $\mathrm{CCl}_{4}$ to $\mathrm{CHCl}_{3}$ in rats. In the present studies, greater quantities of $\mathrm{CHCl}_{3}$ were found in rats after a single $7500 \mathrm{ppm}$ exposure than in those exposed to $4000 \mathrm{ppm}$ and $48 \mathrm{hr}$ later reexposed to $7500 \mathrm{ppm}$ of $\mathrm{CCl}_{4}$. The in vitro studies similarly show that the conversion of $\mathrm{CCl}_{4}$ to $\mathrm{CHCl}_{3}$ by normal rat livers is about four times faster than in rats previously exposed to $4000 \mathrm{ppm}$ of $\mathrm{CCl}_{4}$, suggesting that a direct relationship may exist between the rate of metabolism of carbon tetrachloride and its toxicity.

The formation of free radicals during metabolism of $\mathrm{CCl}_{4}$ has been suggested by Butler (1961). Wirtschafter and Cronyn (1964) also studied the free radical mechanism and suggested that the toxicity of $\mathrm{CCl}_{4}$ and $\mathrm{CHCl}_{3}$ is the result of free radical cleavage and the subsequent combination of the free radicals with cell constituents. The protective action of various antioxidants (Gallagher, 1962) also lends support to the hypothesis that the breakdown of $\mathrm{CCl}_{4}$ with the formation of free radicals may be the initial step in $\mathrm{CCl}_{4}$ toxicity. For details of the various theories of $\mathrm{CCl}_{4}$ toxicity, one should consult the comprehensive review by Recknagel (1967). In the present study, preexposure to $\mathrm{CCl}_{4}$ decreased the rate of $\mathrm{CCl}_{4}$ metabolism and might have protected the animal against subsequent high level exposures by diminishing the formation of active free radical 
intermediates. A mechanism of toxicity, based upon the metabolism of $\mathrm{CCl}_{4}$ is consistent with results obtained in the present study.

\section{ACKNOWLEDGMENT}

This study was supported in part by U.S. Public Health Service research grant R01 EC 00198-08.

\section{REFERENCES}

Am Assoc. Clin. Chem. (1953). Standard Methods of Clinical Chemistry, Vol. 1 (M. Reiner, ed.). Academic Press, New York.

BARNOTHY, M. F. (1963). Reduction of radiation mortality through magnetic pretreatment. Nature 200, 279-280.

BLOCK, W. D., CORNISH, H. H. (1958). Effect of carbon tetrachloride inhalation on rat serum enzymes. Proc. Soc. Exptl. Biol. Med. 97, 178.

Brauer, R. W., LeONG, G. F., and Holloway, R. J. (1961). Liver injury in isolated perfused rat liver preparation exposed to chloroform. Am.J. Physiol. 200, 348-350.

BUTLER, T. C. (1961). Reduction of carbon tetrachloride In vivo and reduction of carbon tetrachloride and chloroform in vitro by tissues and tissue constituents. J. Pharmacol. Exptl. Therap. 134, 311-319.

Butler, W. M., JR., Maling, H. M., Horning, M. G., and Brodie, B. B. (1961). The direct determination of liver triglycerides. J. Lipid Res. 2, 95-96.

DunCaN, D. B. (1955). Multiple range and multiple F tests. Biometrics 11, 1-42.

Gallagher, C. H. (1962). The effect of antioxidants on poisoning by carbon tetrachloride. Australian J. Exptl. Biol. Med. Sci. 40, 241-254.

Hattori, K., Kato, N., Kinoshita, M., Kinoshita, S., and Sunada, T. (1963). Protective effect of ozone in mice against whole body X-irradiation. Nature 198, 1220.

Heimberg, M., Weinstein, I., Dishmon, G., and Dunkerley, A. (1962). The action of carbon tetrachloride on the transport and metabolism of triglycerides and fatty acids by the isolated perfused rat liver and its relationship to the etiology of fatty liver. J. Biol. Chem. 237, $3623-3627$.

LomBardi, B. (1965). Pathogenesis of fatty liver. Federation Proc. 24, 1200-1205.

Paul, B. B., and Rubinstein, D. (1963). Metabolism of carbon tetrachloride and chloroform by the rat. J. Pharmacol. Exptl. Therap. 141, 141-147.

Recknagel, R. O. (1967). Carbon tetrachloride hepatotoxicity. Pharmacol. Rev. 4, 145-208.

ReCKNAGel, R. O., and Ghoshal, A. K. (1966). Lipoperoxidation as a vector in carbon tetrachloride hepatotoxicity. Lab. Invest. 15, 132-146.

Seakins, A., and Robinson, D. S. (1963). The effect of the administration of carbon tetrachloride on the formation of plasma lipoproteins in the rat. Biochem. J. 86, 401-407.

Smuckler, E. A., Iseri, O. A., and BenditT, E. P. (1961). Studies on carbon tetrachloride intoxication, Biochem. Biophys. Res. Commun. 5, 270-275.

Stokinger, H. E. (1965). Ozone toxicology. A.M.A. Arch. Environ. Health 10, 719-731.

Stokinger, H. E., and Scheel, L. D. (1962). Ozone toxicity. A.M.A. Arch. Environ. Health 4, 327-334.

Terhaar, C. J., Vis, E., Roudabush, R. L., and Fassett, D. W. (1965). Protective effects of low doses of cadmium chloride against subsequent high oral doses in the rat. Toxicol. Appl. Pharmacol. 7, 500 (Abstract).

VAN HANDEL, E., and ZiLversmit, D. B. (1957). Micromethod for the direct determination of serum triglycerides. J. Lab. Clin. Med. 1, 152-157.

WIRTSChAFTER, Z. T., and CronYN, M. W. (1964). Free radical mechanism for solvent toxicity. A.M.A. Arch. Environ. Health 9, 186191. 